\title{
Efficacy of sustained release ciprofloxacin microspheres against device-associated Pseudomonas aeruginosa biofilm infection in a rabbit peritoneal model
}

\author{
G. OWUSU-ABABIO*‡, J. A. ROGERS*\&, D. W. MORCK† and M. E. OLSON $\dagger$ \\ * Faculty of Pharmacy and Pharmaceutical Sciences, University of Alberta, Edmonton, Alberta, Canada T6G 2N8 and \\ + Biofilm Research Group, University of Calgary, Calgary, Alberta, Canada T2N 4N1
}

\begin{abstract}
Summary. The relative effectiveness of a poly(L-lactic acid) ciprofloxacin hydrochloride (CIP) microsphere formulation $(250-425 \mu \mathrm{m})$ against peritoneal implanted biofilm of Pseudomonas aeruginosa was investigated in a rabbit model. Correlations between in-vivo CIP pharmacokinetics in peritoneal dialysate and serum after intraperitoneal administration, in-vivo cell counts and rabbit survival rate were obtained. Dialysate and serum concentrations after $12 \mathrm{~h}\left(\mathrm{C}_{12 \mathrm{~h}}\right)$ were greater than those obtained with free drug whereas maximum serum concentrations $\left(\mathrm{C}_{\max }\right)$ were lower and the time to reach $\mathrm{C}_{\max }\left(\mathrm{t}_{\max }\right)$ was longer. A silastic implant device pre-colonised with $P$. aeruginosa for 2 days was implanted in the rabbit peritoneum, and dialysate with or without drug or microspheres was administered via a catheter. Rabbits receiving no antibiotic and those receiving free drug (10 $\mathrm{mg}$ in dialysate) died of peritonitis and septicaemia, whereas all rabbits given CIP microspheres recovered completely from infection. The viable count of $P$. aeruginosa was markedly reduced or eliminated from the catheter, the device and the peritoneal wall in CIP microsphere-treated rabbits but not in rabbits treated with free drug, as determined from histological and scanning electronmicroscopic evidence. These results demonstrate that sustained release of antibiotics at biofilm eradication concentrations (BEC) is required to treat biofilm infections associated with peritoneal implanted devices.
\end{abstract}

\section{Introduction}

Implanted medical or prosthetic devices have saved and improved the quality of human lives over the short- or long-term. ${ }^{1.2}$ However, a major problem associated with aortic interposition grafts, peritoneovenous shunts, ventriculoperitoneal shunts, t-tubes and peritoneal dialysis catheters is the occurrence of infections. ${ }^{3}$ Although most implant-related infections are caused by gram-positive bacteria, infections caused by gram-negative bacteria are potentially more serious. ${ }^{3.4}$ These are complicated by the presence of a bacterial biofilm of microbes that are able to attach firmly to solid surfaces, such as catheters and prosthetic devices, and produce a glycocalyx matrix inside which microcolonies coalesce and thrive..$^{15-7}$ The establishment of biofilm by invading pathogens provides survival advantages and, consequently, host

Received 8 Sept. 1994; revised version accepted 26 March 1995.

$\ddagger$ Present address: Department of Pharmaceutics, College of

Pharmacy and Pharmaceutical Sciences, Howard University, 2300

4th Street NW, Washington, DC 20059, USA.

$\S$ Correspondence should be sent to Dr J. A. Rogers immune defences are less effective..$^{5,8}$ At the same time there is increased resistance to antibiotics. ${ }^{9-11}$

Peritoneal dialysis has been recognised as a major form of therapy in chronic renal failure, but its application is often limited by recurrent peritonitis, ${ }^{12,13}$ especially involving biofilm associated with peritoneal catheters. ${ }^{14-16}$ The principal pathogens responsible for peritonitis in continuous ambulatory peritoneal dialysis (CAPD) are Staphylococcus epidermidis, $S$. aureus, Escherichia coli and Pseudomonas aeruginosa. ${ }^{17-19}$ The current mode of treatment of CAPD peritonitis is by administration of antibiotics in peritoneal dialysate solution. ${ }^{20-24}$ The elimination halflife of most antibiotics in the peritoneum is shorter than in the serum because of rapid transperitoneal absorption. In peritonitis, the peritoneal membrane has an increased permeability; therefore, the half-life of the antibiotic in the peritoneum is further reduced compared to patients without peritonitis. ${ }^{20.24}$ Although intraperitoneal administration of antibiotics, including ciprofloxacin hydrochloride (CIP), appears to be effective initially, the emergence of resistant strains and recurrent peritonitis are still 
problems. ${ }^{21-23}$ This may be attributed to the occurrence of bacterial biofilm on peritoneal catheters as a result of sub-therapeutic concentrations of antibiotic in the peritoneum towards the end of the dwell time. This problem could be overcome by the administration of a sustained release antibiotic formulation such as a micro-particle that delivers the antibiotic continuously during the dwell time of the peritoneal dialysate.

The formulation of CIP in biodegradable polymeric microspheres has been reported previously ${ }^{25}$ and the effectiveness of microspheres in eradicating bacterial biofilms of $P$. aeruginosa and $S$. aureus in the open chemostat has been demonstrated. ${ }^{26} \mathrm{CIP}$ was chosen for this study because it is very active against both gram-positive and gram-negative bacteria in vitro $^{27}$ and it has been administered in peritoneal dialysate to treat CAPD peritonitis in the clinic. ${ }^{21-23}$ The aims of this study were to determine the pharmacokinetics of micro-encapsulated and free CIP in a rabbit peritoneal model, and to determine the effectiveness of a sustained release CIP microsphere formulation in treating $P$. aeruginosa biofilm thriving on an implanted "lifesaver device" and a catheter in the peritoneum of the rabbit.

\section{Materials and methods}

\section{Materials}

Disks of silastic subdermal implant devices and CAPD catheters with dacron cuffs (9 FR ID) were made from silicone sheets or tubing (Dow Corning Corp., Medical Products, Midland, MI, USA). Adult, female New Zealand White (NZW) rabbits (Vandermeer C., Sherwood Park, Alberta, Canada) weighing $3-3.5 \mathrm{~kg}$ were used in all experiments. A laboratory strain of $P$. aeruginos $a \mathrm{PAO}^{28}$ was used for pre-colonisation of the devices. Poly(L-lactic acid) (PLA) was obtained from Polysciences, Warrington, PA, USA and CIP was a gift from Miles Canada Inc., Etobicoke, Ontario, Canada.

\section{Microsphere preparation}

Microspheres of CIP were prepared with a phase separation technique described previously. ${ }^{26}$ Briefly, $1 \mathrm{~g}$ of CIP was dispersed in $10 \mathrm{ml}$ of a methylene chloride solution containing $100000 \mathrm{~mol}$. wt PLA $400 \mathrm{mg}$. This was stirred magnetically $(400 \mathrm{rpm})$ while diethylether was metered into the dispersion at a rate of $0.2 \mathrm{ml} / \mathrm{min}$ causing co-acervation of the polymer. The microspheres which formed were harvested and dried then sieve-sized. A $250-425-\mu \mathrm{m}$ fraction was used for testing in the rabbits.

\section{Pharmacokinetics of micro-encapsulated and free ciprofloxacin}

Six adult female NZW rabbits were placed under halothane anaesthesia in the left lateral recumbency.
The entire area from the dorsal mid-line to the ventral mid-line, and from the point of the hip to the midthorax were shaved and given three surgical scrubs with Betadine solution and spray (Purdue Fredric Co., Toronto, Ontario, Canada). Also, the right jugular vein and dorsal mid-line area were shaved and prepared surgically. A mid-line incision was made and a CAPD catheter was placed in the abdomen with the external segment tunnelled subcutaneously to the dorsal mid-line. The distal end of the catheter was then exteriorised and attached to an injection adaptor. The right jugular vein was exposed and cannulated with a $5 \mathrm{~F}$ intravenous (i.v.) catheter. ${ }^{29} \mathrm{~A}$ skin incision was made over the dorsal mid-line of the back to facilitate the subcutaneous tunnelling of the i.v. catheter. A three-way stopcock and a butterfly bandage were sutured securely in place. An i.v. drip was connected and i.v. fluid (dextrose $5 \%+$ no. 75 electrolyte, Baxter, Deerfield, IL, USA) was administered to ensure i.v. catheter patency. The rabbits were allowed to recover and then placed in individual restraining cages.

The rabbits initially received $250 \mathrm{ml}$ of peritoneal dialysate (Dianeal, Baxter); they were then divided into three groups of two rabbits. After $12 \mathrm{~h}$, the rabbits received a further $250 \mathrm{ml}$ of peritoneal dialysate. In addition, groups 1,2 and 3 received $9 \mathrm{mg}$ of blank microspheres, free CIP $10 \mathrm{mg}$ or CIP $20 \mathrm{mg}$ in microspheres, respectively, in peritoneal dialysate. Peritoneal fluid $(2 \mathrm{ml})$ was withdrawn through the peritoneal catheter at times $0,0 \cdot 5,1,2,4,6,8,10$ and $12 \mathrm{~h}$. These samples were centrifuged, then stored at $-20^{\circ} \mathrm{C}$ until required for analysis. A 2-ml sample of blood was also withdrawn via the jugular vein at approximately the same time, placed in serum separator tubes (Corvac, Sherwood Medical, St Louis, MO, USA) and centrifuged. The serum was removed and stored at $-20^{\circ} \mathrm{C}$.

Analysis of CIP in peritoneal dialysate and serum. A serum sample $(0.5 \mathrm{ml})$ was combined with $0.5 \mathrm{ml}$ of acetonitrile to precipitate protein and centrifuged $(5000 \mathrm{~g}, 5 \mathrm{~min})$. A $0 \cdot 7-\mathrm{ml}$ sample of supernate was evaporated to dryness and reconstituted with $0.5 \mathrm{ml}$ of phosphate-buffered saline (PBS, $\mathrm{pH} \mathrm{7.4)} \mathrm{containing}$ quinine sulphate $5 \mathrm{mg} / \mathrm{L}$ (as the HPLC internal standard). Diluted samples of peritoneal dialysate containing internal standard were also prepared. CIP was assayed by reverse phase HPLC. Conditions of assay were a $\mathrm{C}_{18}$ Nova-Pak column (Waters-Millipore Corp., Milford, MA, USA), a Waters 501 pump connected to a WISP automatic sampler and a Waters 740 scanning fluorescence detector. Excitation and emission wavelengths were set at 280 and $455 \mathrm{~nm}$, respectively. The mobile phase consisted of acetonitrile: $33.5 \mathrm{~mm}$ phosphate buffer $(16.5: 83.5 \mathrm{v}: \mathrm{v})$ adjusted to $\mathrm{pH} 3.0$ with glacial acetic acid. Retention times were 4.3 and $7.9 \mathrm{~min}$ for ciprofloxacin and quinine sulphate, respectively. The sensitivity of the assay was $0.01 \mathrm{mg} / \mathrm{L}$ and linear regression analyses of standard calibration curves yielded a correlation of 0.999 over the range $0.02-10 \mathrm{mg} / \mathrm{L}$. The daily coefficient of variation was $<4 \%$. 
Procedure for testing CIP formulations ayainst severe device-related biofilm infections

Lifesaver implant devices. The lifesaver devices were constructed according to Ward et al. ${ }^{28}$ Briefly, $1.5-\mathrm{cm}$ diameter disks of silastic subdernwal implant material were attached to both sides of six Teflon support disks of the same diameter. The support disks were then suspended on a $4.0-\mathrm{cm}$ Teflon rod separated by $2-\mathrm{mm}$ Teflon spacers. The total surface area of the silastic material for each device was $32 \mathrm{~cm}^{2}$. The devices were sterilised with ethylene oxide for $4 \mathrm{~h}$ before colonisation.

Pre-colonisation of implant devices. Fresh, sterilised nutrient broth $(50 \mathrm{ml})$ was inoculated with an active inoculum of $P$. aeruginosa PAO1 $2 \%$. Sterile lifesaver devices were pre-colonised in each broth culture for $48 \mathrm{~h}$ at $37^{\circ} \mathrm{C}$ in a shaker incubator. A total of six lifesaver devices was pre-colonised. After the incubation period, the lifesaver devices were removed aseptically from the broth cultures and rinsed with sterile PBS to remove any planktonic bacteria.

Implantation of lifesaver device. After pre-colonisation, one disk was removed aseptically from each lifesaver device and the number of biofilm cells was determined. During surgery, the device was placed in the peritoneal cavity of a rabbit adjacent to the tip of the CAPD catheter. The device was fixed to the abdominal peritoneal wall with a single 2-0 polypropylene suture (Prolene. Ethicon. Peterborough, Ontario, Canada). After recovery, all the rabbits were placed in individual cages and monitored daily for food and water consumption, urination, defaecation and incision site abnormalities.

Treatment with micro-encapsulated or free CIP. Initially (run 1), six rabbits, divided into three groups of two, received $9 \mathrm{mg}$ of blank microspheres, free CIP $10 \mathrm{mg}$, or CIP $20 \mathrm{mg}$ in PLA microspheres, respectively. Subsequently (run 2), six rabbits divided into two groups of three received either free CIP $10 \mathrm{mg}$ or CIP $20 \mathrm{mg}$ in PLA microspheres, respectively. In each case, the formulation was administered in the dialysate. Twenty-four $h$ after implantation of a lifesaver device during run 1 , each rabbit received peritoneal dialysate $250 \mathrm{ml}$ and was observed for symptoms of infection. After $12 \mathrm{~h}$ of dwell time, residual dialysate was removed from the peritoneum and the numbers of viable planktonic cells were determined. The rabbits received an additional $250 \mathrm{ml}$ of dialysate containing a formulation and were observed for a further $12 \mathrm{~h}$ then the experiment was terminated. Run 2 was modified such that $250 \mathrm{ml}$ of dialysate containing a formulation was administered only $12 \mathrm{~h}$ after implantation of a lifesaver device. The administration of dialysate and formulation was repeated every $12 \mathrm{~h}$ for 2 days; each time the residual dialysate was removed and viable cell counts were determined.

Determination of tiable bacterial cells. Each disk of the lifesaver device was washed with $2 \mathrm{ml}$ of PBS to remove surface planktonic cells. Each side of the disk was scraped with a sterile scalpel blade into $2 \mathrm{ml}$ of sterile PBS; the suspension was sonicated, serially diluted and plated on nutrient agar. After $18 \mathrm{~h}$, the colonies were counted to determine the concentration of the colony-forming units of the disk $\left(\mathrm{cfu} / \mathrm{cm}^{2}\right)$. Populations of planktonic cells in residual dialysate $(\mathrm{cfu} / \mathrm{ml})$ were determined from serially diluted samples incubated on nutrient agar plates.

\section{Post-mortem examination}

Samples of the lifesaver device, the CAPD catheter and the peritoneal wall were collected from animals immediately after they died of infection or after they were killed $24 \mathrm{~h}$ after the last dose. Bacterial counts were obtained from peritoneal fluids, lifesaver devices, interior and exterior walls of the CAPD catheter, and the peritoneal walls of the rabbits. Bacteria were enumerated as described above. The peritoneal wall tissues associated with the implant device were fixed in neutral buffered formalin, sectioned and stained with haematoxylin and eosin according to standard procedures. Histological sections were examined by light microscopy by a veterinary pathologist. Scanning electronmicroscopy (SEM) was used to study the surface of one of the disks of each implanted lifesaver device and of the CAPD catheter following the procedure of Ward et al..$^{28}$

\section{Results}

The mean concentrations of CIP in peritoneal dialysate over a period of $12 \mathrm{~h}$ are shown in fig. 1 and relevant pharmacokinetic parameters are given in table I. Since free drug is dissolved in the dialysate, only its elimination kinetics are described in fig. 1, which indicates that its concentration decreased exponentially from an initial $40 \mathrm{mg} / \mathrm{L}$ to about $20 \mathrm{mg} / \mathrm{L}$ after $1 \mathrm{~h}$. In contrast, the kinetics of CIP released from microspheres resulted in increasing dialysate con-

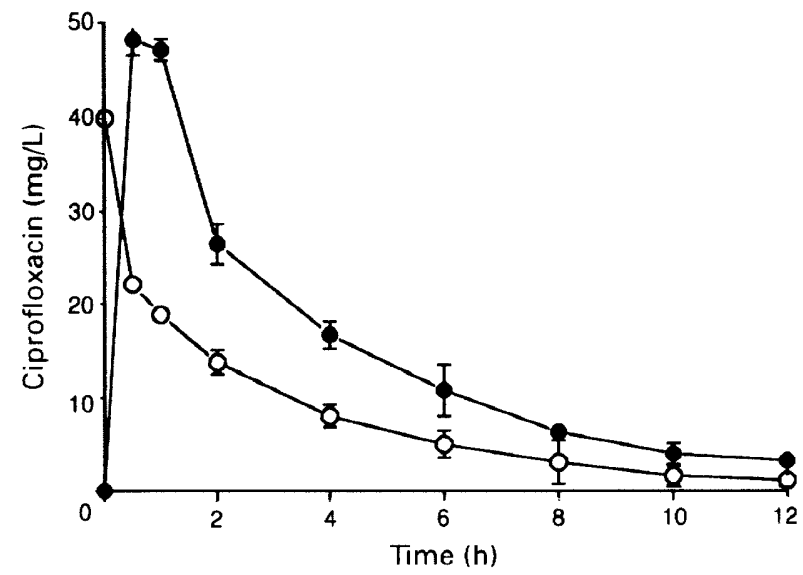

Fig. 1. Mean dialysate concentrations as a function of time for two groups of rabbits after a single i.p. dose of: $O$. Free CIP $0 \mathrm{mg}$; CIP $20 \mathrm{mg}$ in PLA microspheres. 
Table I. Kinetics of CIP removal from peritoneal dialysate in rabbits after administration in peritoneal dialysate of $20 \mathrm{mg}$ of CIP in microspheres or $10 \mathrm{mg}$ of free CIP

\begin{tabular}{|c|c|c|c|}
\hline Formulation & $\begin{array}{c}\mathrm{C}_{\max }{ }^{*} \\
(\mathrm{mg} / \mathrm{L})\end{array}$ & $\frac{\mathrm{t}_{\max }}{\text { (h) }}$ & $\begin{array}{c}\mathrm{C}_{12 \mathrm{~h}} \stackrel{\ddagger}{\ddagger} \\
(\mathrm{mg} / \mathrm{L})\end{array}$ \\
\hline Free drug & $40(0 \cdot 0)$ & $0 \cdot 0(0.0)$ & $1.0(0.3)$ \\
\hline Microsphere & $48(1 \cdot 6)$ & $0.5(0.0)$ & $2 \cdot 9(0 \cdot 2)$ \\
\hline
\end{tabular}

* Maximum concentration attained in the peritoneal dialysate. Standard error of the mean (SEM) is shown in brackets, $\mathrm{n}=3$. $\dagger$ Time to reach $\mathrm{C}_{\max }$

$\ddagger$ Concentration after $12 \mathrm{~h}$.

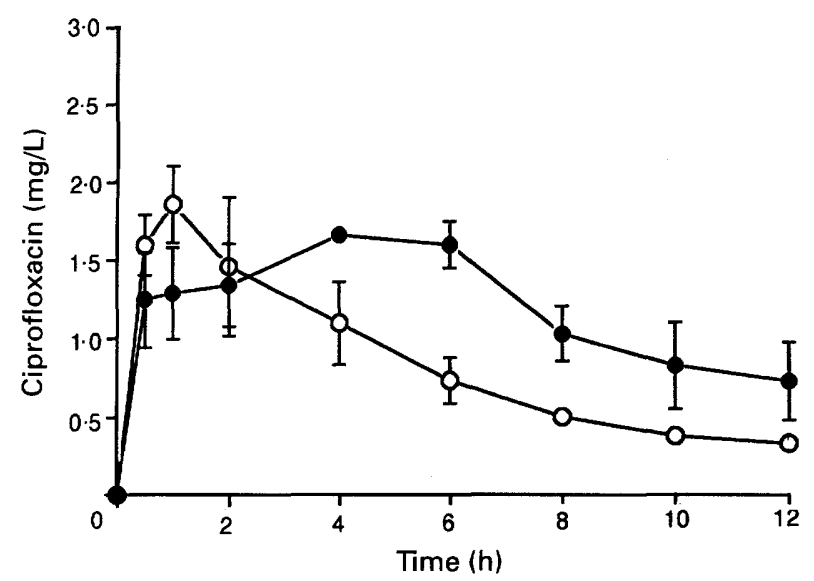

Fig. 2. Mean serum concentrations as a function of time for two groups of rabbits $(n=3)$ after a single i.p. dose of: $O$, Free CFX $0 \mathrm{mg} ;-$ CIP $20 \mathrm{mg}$ in microspheres.

Table II. Kinetic profile of CIP in serum of rabbits after administration in peritoneal dialysate of $20 \mathrm{mg}$ of CIP in microspheres or free CFX $10 \mathrm{mg}$

\begin{tabular}{lccc}
\hline Formulation & $\begin{array}{c}\mathrm{C}_{\max }{ }^{*} \\
(\mathrm{mg} / \mathrm{L})\end{array}$ & $\begin{array}{c}\mathrm{t}_{\text {max }}{ }^{\dagger} \\
(\mathrm{h})\end{array}$ & $\begin{array}{c}\mathrm{C}_{12 \mathrm{n}}^{\ddagger} \\
(\mathrm{mg} / \mathrm{L})\end{array}$ \\
\hline Free drug & $1 \cdot 9(0 \cdot 3)$ & $1 \cdot 0(0 \cdot 0)$ & $0 \cdot 3(0 \cdot 1)$ \\
Microsphere & $1 \cdot 6(0 \cdot 1)$ & $4 \cdot 0(1 \cdot 0)$ & $0 \cdot 7(0 \cdot 3)$
\end{tabular}

*Maximum concentration in the serum. SEM shown in brackets, $\mathrm{n}=3$.

$\dagger$ Time to reach $\mathrm{C}_{\max }$.

$\ddagger$ Concentration after $12 \mathrm{~h}$.

centrations, reaching a $\mathrm{C}_{\max }$ within $30 \mathrm{~min}$ of c. $50 \mathrm{mg} / \mathrm{L}$ then falling exponentially after $1 \mathrm{~h}$, i.e., $\mathrm{C}_{\max }$ was maintained for $30 \mathrm{~min}$. Consequently, the dialysate concentration after $12 \mathrm{~h}$ was approximately three times higher than that obtained from free drug administered in dialysate (table I).

The corresponding serum concentrations of CIP are shown in fig. 2 and the pharmacokinetic parameters are given in table II. The serum concentration-time profile obtained from the solution formulation typically shows drug absorption and elimination phases resulting in decreasing CIP concentrations from a peak of $1.9 \mu \mathrm{g} / \mathrm{ml}\left(\mathrm{C}_{\max }\right)$ after $1 \mathrm{~h}\left(\mathrm{t}_{\max }\right)$ to about $0 \cdot 3 \mu \mathrm{g} / \mathrm{ml}$ after $12 \mathrm{~h}$. In comparison, when CIP microspheres were administered to the rabbits in peritoneal dialysate, serum concentrations increased
Table III. Population of viable planktonic cells determined in residual peritoneal dialysate of rabbits $12 \mathrm{~h}$ after administration of free CIP (group 1) or CIP in microspheres (group 2)

\begin{tabular}{ccc}
\hline \multirow{2}{*}{ Time (h) } & \multicolumn{2}{c}{ Mean (SEM) viable count $\left(\log _{10} \mathrm{cfu} / \mathrm{ml}\right)$} \\
\cline { 2 - 3 } & Group 1* & Group 2† \\
\hline \multirow{2}{*}{12} & $4.04(0.02)$ & NG \\
24 & $3.56(0.07)$ & $1.56(0.49)$ \\
36 & 2.9 & $1.40(0.12)$ \\
\hline
\end{tabular}

NG, no growth.

*Mean CIP concentration $12 \mathrm{~h}$ after each administration of free CIP was $1 \cdot 1(0 \cdot 3) \mathrm{mg} / \mathrm{L}, \mathrm{n}=3$. Only one rabbit in this group survived after $36 \mathrm{~h}$.

†Mean CIP concentration $12 \mathrm{~h}$ after each administration of CIP in microspheres was $2 \cdot 7(0 \cdot 8) \mathrm{mg} / \mathrm{L}, \mathrm{n}=3$.

to $1.6 \mathrm{mg} / \mathrm{L}$ after $4 \mathrm{~h}$ and were maintained at this level for $c .2 \mathrm{~h}$ before decreasing to $c .0 .7 \mathrm{mg} / \mathrm{L}$ after $12 \mathrm{~h}$.

The mean population of viable $P$. aeruginosa cells that colonised each lifesaver device prior to implantation was $9 \times 10^{7} \mathrm{cfu} / \mathrm{cm}^{2}$. In the initial experiment (run 1), the mean population of viable planktonic cells in the dialysate was $2 \times 10^{8} \mathrm{cfu} / \mathrm{ml}$ after $24 \mathrm{~h}$ prior to dosing and the rabbits appeared severely infected and lethargic. Even after treatment protocols were initiated, the rabbits showed symptoms of septic shock within $2 \mathrm{~h}$ and both rabbits in group 1 (no antibiotic), both rabbits in group 2 (free antibiotic), and one of two rabbits in group 3 (CIP microspheres) died within the ensuing $24 \mathrm{~h}$. Post-mortem examination of these rabbits indicated that death was associated with bacterial endotoxaemia and septicaemia. The one surviving rabbit that had received CIP microspheres recovered to normal health. Unfortunately, the other rabbit in group 3 had already succumbed to the infection and did not respond to treatment. Since it was demonstrated that peritonitis in untreated rabbits was rapidly fatal this group of untreated rabbits was not included in run 2 .

In run 2 , analysis of residual peritoneal dialysate after $12 \mathrm{~h}$ from group 1 rabbits, in which free CIP in dialysate solution had been administered, yielded a mean planktonic cell population of $P$. aeruginosa of $1 \cdot 1 \times 10^{4} \mathrm{cfu} / \mathrm{ml}$ and these levels remained high even after $36 \mathrm{~h}$. In contrast, the residual dialysate in group 2 rabbits, in which CIP microspheres had been suspended, was free of viable planktonic cells after $12 \mathrm{~h}$ (table III). After $24 \mathrm{~h}$, two of the rabbits in group 1 had died of endotoxaemia and septicaemia and the third rabbit was very sick, whereas all three rabbits in group 2 survived and were determined to be clinically normal. Also, 24 and $36 \mathrm{~h}$ after CIP microsphere administration, the levels of planktonic cells in the residual dialysates of rabbits in this group were very low (table III).

The population of viable bacterial cells/g of peritoneal wall tissue examined was $c .1000$ times larger in the surviving rabbit of group 1 that received free CIP compared to the mean population of cells found 
Table IV. Recovery of $P$. aeruginosa from silastic implant, peritoneal wall and residual peritoneal dialysate of rabbits $24 \mathrm{~h}$ after the final administration of free CIP (group 1, one rabbit) or CIP in microspheres (group 2, three rabbits)

\begin{tabular}{|c|c|c|c|c|c|}
\hline \multirow{3}{*}{$\begin{array}{l}\text { Rabbit } \\
\text { group }\end{array}$} & \multicolumn{5}{|c|}{ Mean (SEM) viable count from } \\
\hline & \multirow{2}{*}{$\begin{array}{c}\text { Silastic } \\
\text { implant* } \\
\left(\log _{10} \mathrm{cfu} / \mathrm{cm}^{2}\right)\end{array}$} & \multicolumn{2}{|c|}{ Peritoneal catheter } & \multirow{2}{*}{$\begin{array}{c}\text { Peritoneal } \\
\quad \text { wall } \\
\left(\log _{10} \mathrm{cfu} / \mathrm{g}\right)\end{array}$} & \multirow{2}{*}{$\begin{array}{c}\text { Peritoneal } \dagger \\
\text { fluid } \\
\left(\log _{10} \mathrm{cfu} / \mathrm{ml}\right)\end{array}$} \\
\hline & & $\begin{array}{l}\text { interior wall } \\
\qquad\left(\log _{10} \mathrm{c}\right.\end{array}$ & $\begin{array}{l}\text { exterior wall } \\
\mathrm{fu} / \mathrm{cm})\end{array}$ & & \\
\hline 1 & $7.62(0.27)$ & 5.08 & $4 \cdot 78$ & 9.08 & 6.58 \\
\hline 2 & $5.52(0.20)$ & $2.63(0.83)$ & $2.65(0.83)$ & $5.96(0.07)$ & $3 \cdot 15$ \\
\hline
\end{tabular}

${ }^{*}$ Log cfu $/ \mathrm{cm}^{2}$ of Silastic. Three disks/implant/rabbit.

tDialysate was recovered from only one rabbit in group 2.

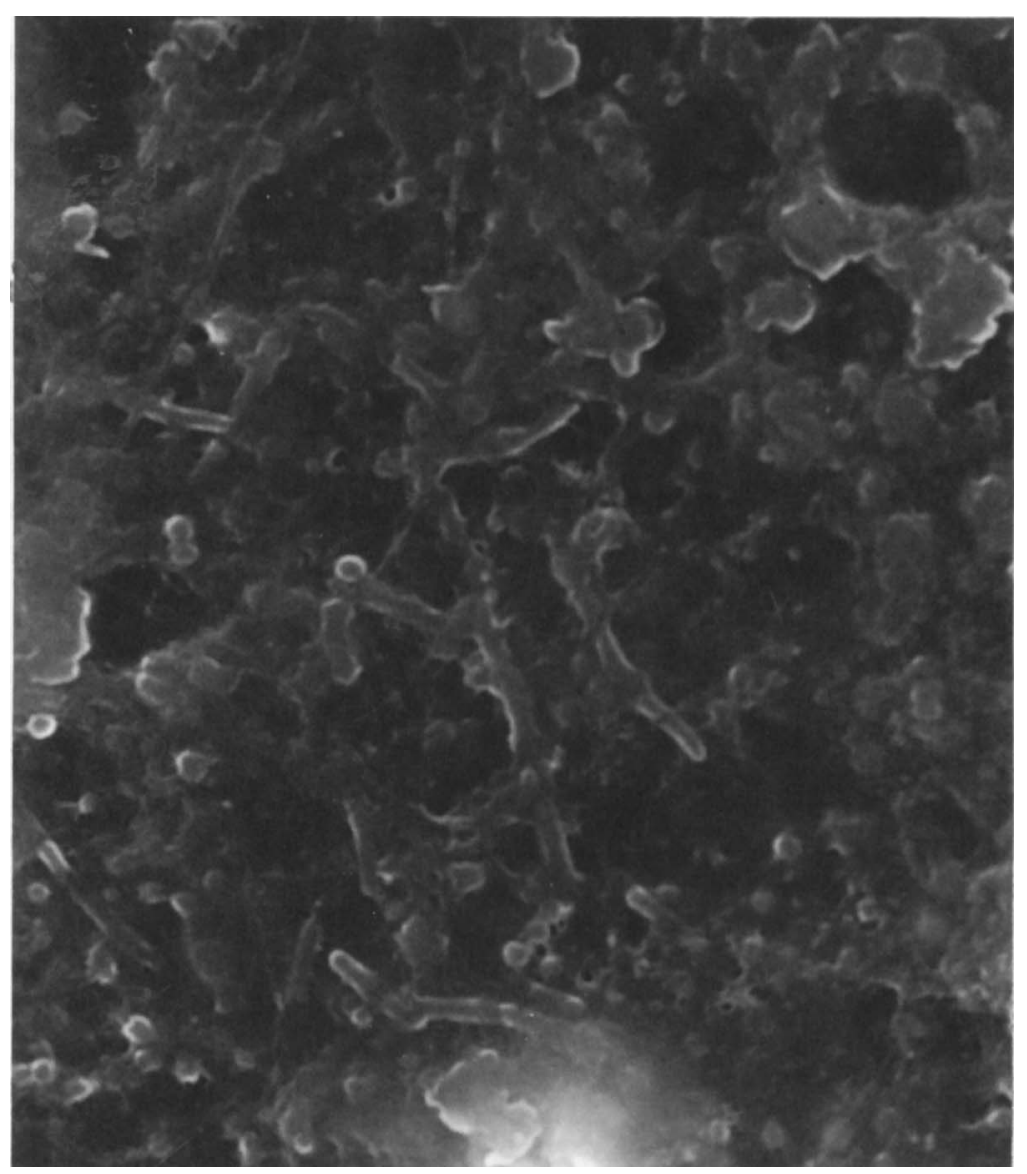

Fig. 3. Scanning electronmicrograph of the interior of the CAPD catheter of a group 1 rabbit (run 2) after treatment with free CIP. Note the thick biofilm and numerous bacteria embedded within the biofilm $(\mathrm{bar}=5 \mu \mathrm{m})$.

associated with a single sample of tissue in rabbits of group 2 that received CIP microspheres (table IV). Also, the mean population of cells $(\mathrm{cfu} / \mathrm{cm})$ of interior or exterior wall material of the peritoneal catheter from group 2 rabbits was $c$. 200 times less than that found in group 1 rabbits. Actually, no viable cells were detected on the catheter or the silastic implant or in the residual dialysate of one rabbit in group 2 , and disks from the lifesaver device in two of the three rabbits in group 2 had 100-fold fewer viable cells than those in group 1 rabbits. Recovery of residual dialysate from two of three rabbits in group 2 was incomplete, which resulted in lower CIP concentrations resulting from the dilution after subsequent administration of CIP microspheres in peritoneal dialysate. Nevertheless, there were $c .3000$-fold fewer viable cells found on average in the dialysate fluid of group 2 rabbits.

Scanning electronmicrographs of the catheter and implanted lifesaver device shown in figs. 3-6 and micrographs of histological samples of wall tissue in figs. 7 and 8 support the clinical and microbiological data. The peritoneal wall tissue from group 1 rabbits 


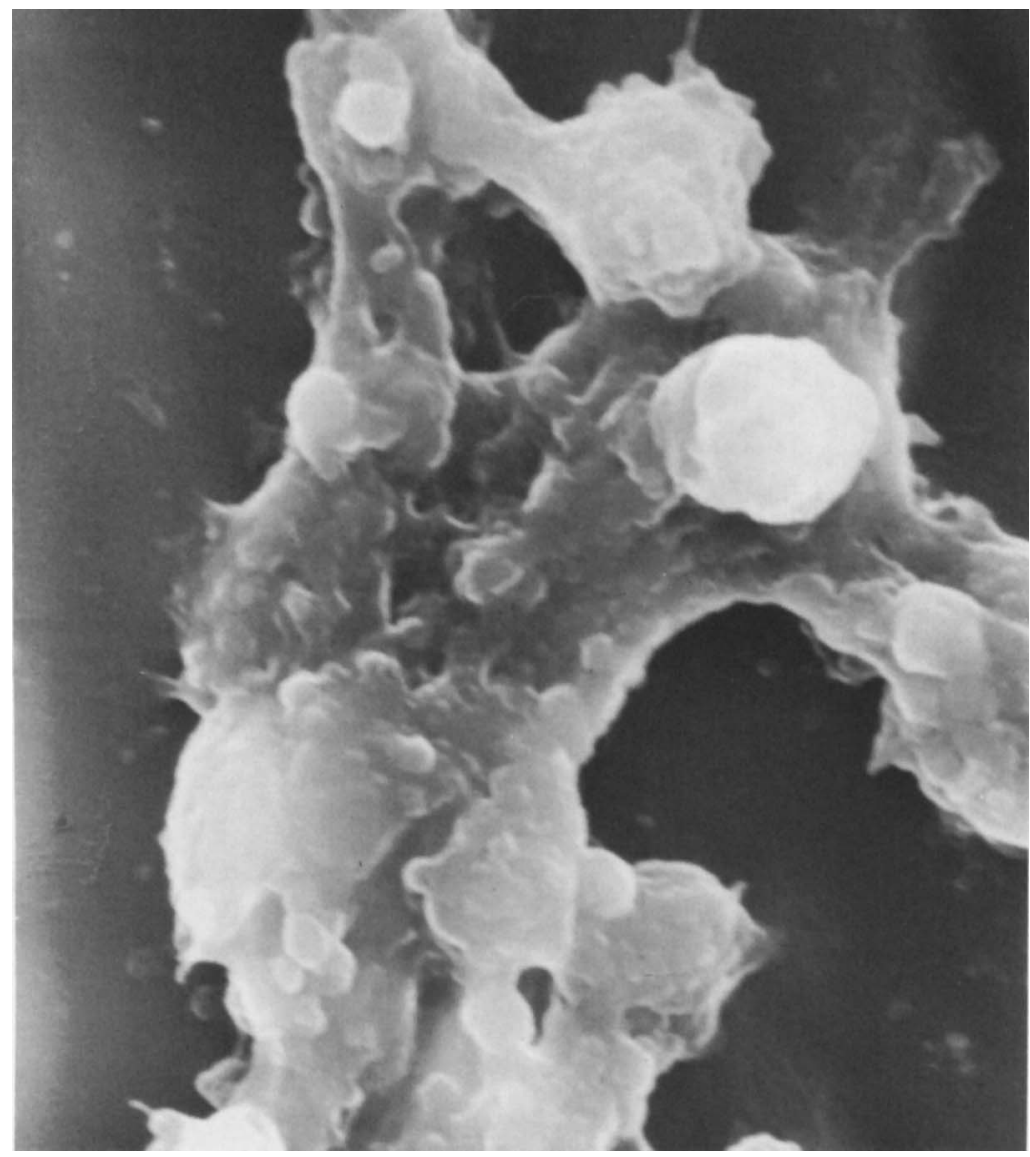

Fig. 4. Scanning electronmicrograph of a disk of the lifesaver device recovered from a group 1 rabbit after treatment with free CIP. There were areas of thick biofilm containing bacteria on the surface of these disks.

was oedematous, necrotic and extensively infiltrated by inflammatory cells (mostly neutrophils) (fig. 7). In comparison, the tissue from group 2 rabbits was only moderately inflamed with little infiltration by inflammatory cells (fig. 8). The interior and exterior of the CAPD catheters from the rabbit in group 1 were colonised with biofilm containing numerous bacteria and, typically, thick biofilm on the interior walls of the catheter can be seen in fig. 3. Similarly, thick biofilm was observed on the disk recovered from this rabbit (fig. 4). The interior and exterior of the CAPD catheters and the disks of group 2 rabbits were free of biofilm and bacteria (figs. 5,6). Only the occasional red blood cell was observed.

\section{Discussion}

These studies have demonstrated unequivocally the health risk for rabbits infected with $P$. aeruginosa device-associated biofilm and viable planktonic cells if not adequately treated. When a bolus dose of CIP in dialysate solution was administered i.p., the drug was cleared rapidly and entered the general circulation. A peak concentration of CIP $1.9 \mathrm{mg} / \mathrm{L}$ in serum occurred after $1 \mathrm{~h}$ but decreased rapidly, reaching $0.7 \mathrm{mg} / \mathrm{L}$ after $6 \mathrm{~h}$ and $0.3 \mathrm{mg} / \mathrm{L}$ after $12 \mathrm{~h}$. The MIC of CIP against $P$. aeuginosa planktonic cells in nutrient broth has been reported to be in the range $0 \cdot 125-1.0 \mathrm{mg} / \mathrm{L}^{30}$ Rabbits that had received $10 \mathrm{mg}$ of free CIP succumbed to the infection and died within $12 \mathrm{~h}$ even though the CIP concentration $12 \mathrm{~h}$ after administration was 1.1 SEM $0.3 \mathrm{mg} / \mathrm{L}(\mathrm{n}=3)$. This indicates that resistant biofilm on the silastic implant and catheter, and not planktonic cells, was mainly responsible for the death of the rabbits. The mortality of the rabbits could possibly have been reduced if frequent injections or infusion of antibiotic had been administered instead, but these choices are neither convenient for the patient nor economical. On the other hand, a sustained release microsphere formulation of CIP was able to treat the infection and prevent death. Although only one CIP microsphere formulation was tested, the results were remarkably positive. However, it could be argued that optimisation of the treatment protocol should be possible by slight modifications of the formulation.

The effectiveness of a sustained release formulation of CIP could be important to CAPD patients. Biofilm growing mainly in the interior of peritoneal catheters has been thought to be responsible for recurrent peritonitis in CAPD patients. The failure of many 


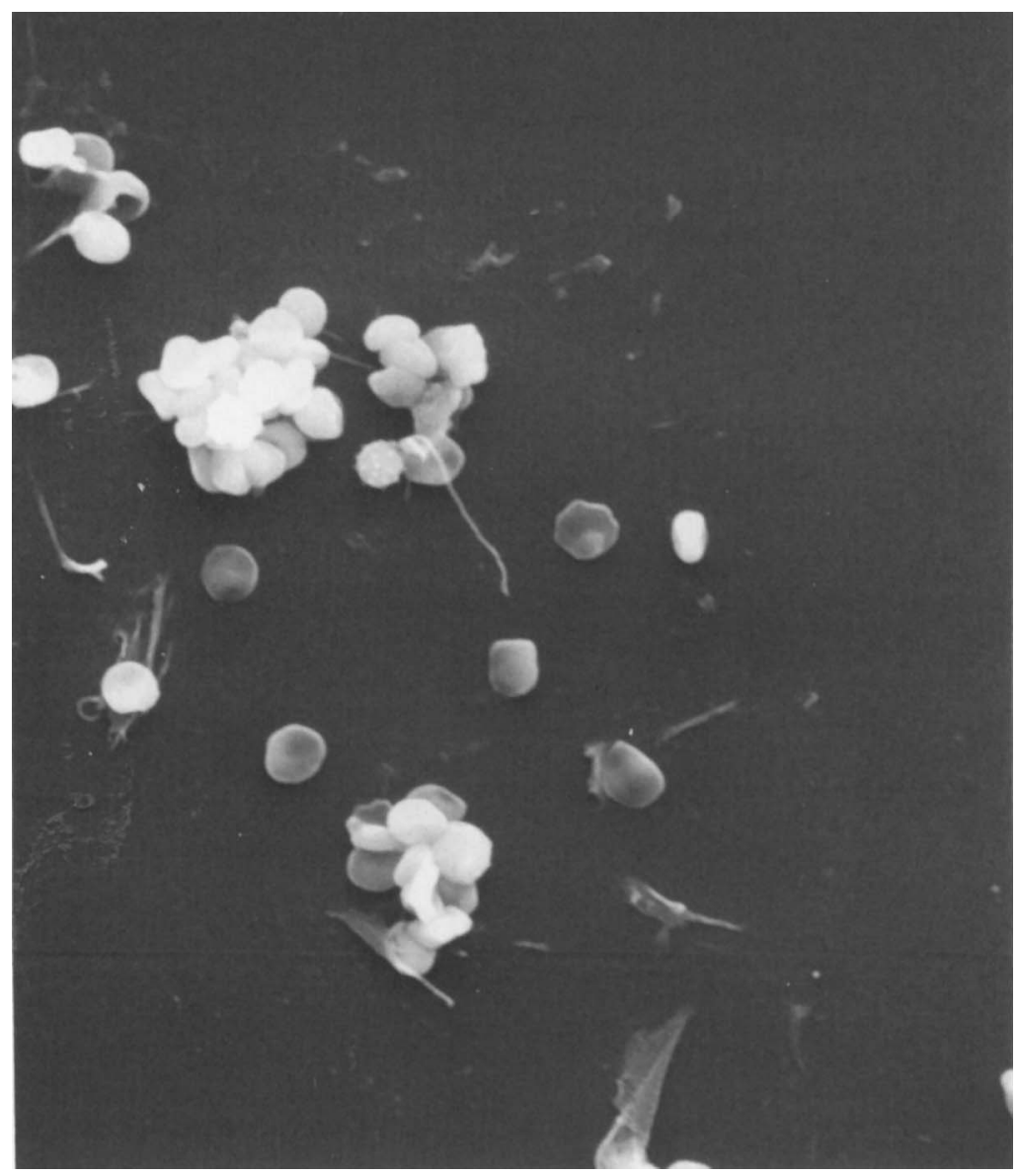

Fig. 5. Scanning electronmicrograph of the interior of the CAPD catheter of a group 2 rabbit after treatment with CIP in microspheres. Note the absence of a biofilm and only the occasional erythrocyte.

treatment modalities with solutions of antibiotics is usually caused by ineffective antibiotic levels in the vicinity of the infecting bacteria, especially those growing in biofilm. It has already been demonstrated in the shake-flask or test tube, which are closed systems, that bacteria in biofilm require a sustained high concentration of antibiotic for their eradication. ${ }^{9-11}$ Although this can be achieved easily in the test tube, this is not the case in vivo because drug is cleared continuously from the fluids adjacent to the site of infection. Such is the case in device-related infections of CAPD patients where it is often difficult to eradicate completely the bacteria because of rapidly diminishing concentrations of antibiotic after administration. After treatment has been stopped, the bacteria, particularly in biofilm, multiply rapidly causing re-infection of the patient. On the other hand, administration of sustained release microspheres can provide concentrations of antibiotic in the vicinity of the biofilm at inhibiting concentrations, i.e., at a biofilm eradicating concentration (BEC) which has been estimated to be $10-500$ times the MIC of the antibiotic for planktonic cells. ${ }^{31.32}$

It is possible, of course, to prepare polymeric microspheres or microcapsules with other polymers and processes to provide the same or other kinetics of release. However, the safety and tissue compatibility of PLA has been well established. ${ }^{33}$ Furthermore, the results of varying several formulation parameters suggested that the $40 / 60$ sieve size fraction $(250-425 \mu \mathrm{m})$ microspheres offered the degree of sustained release required for i.p. administration in the treatment of biofilm infection. The microspheres in peritoneal dialysate were administered easily i.p. via the in-dwelling catheter. Also, the rabbits were not affected adversely by this size range of particles, and being biodegradable, traces of microspheres not removed in the residual dialysate would eventually disappear, although any possible long-term effects of minute quantities of microspheres in the peritoneal cavity were not evaluated.

The dose of CIP in the microspheres employed was selected on the basis of earlier studies and is a function of the loading. ${ }^{26} \mathrm{~A} 20$-mg equivalent dose of CIP in the prepared $(71 \% \mathrm{w} / \mathrm{w})$ microspheres produced a $\mathrm{C}_{\max }$ in serum similar to a 10 -mg dose of free CIP (fig. 2) whereas $\mathrm{C}_{\max }$ and $\mathrm{C}_{12 \mathrm{~h}}$ in dialysate, where the antibiotic is needed, were significantly higher from microspheres (fig. 1). One of the concerns regarding large bolus doses of the fluoroquinolones to treat infections is the degree of toxicity experienced by the patient. However, it can be concluded from this study 


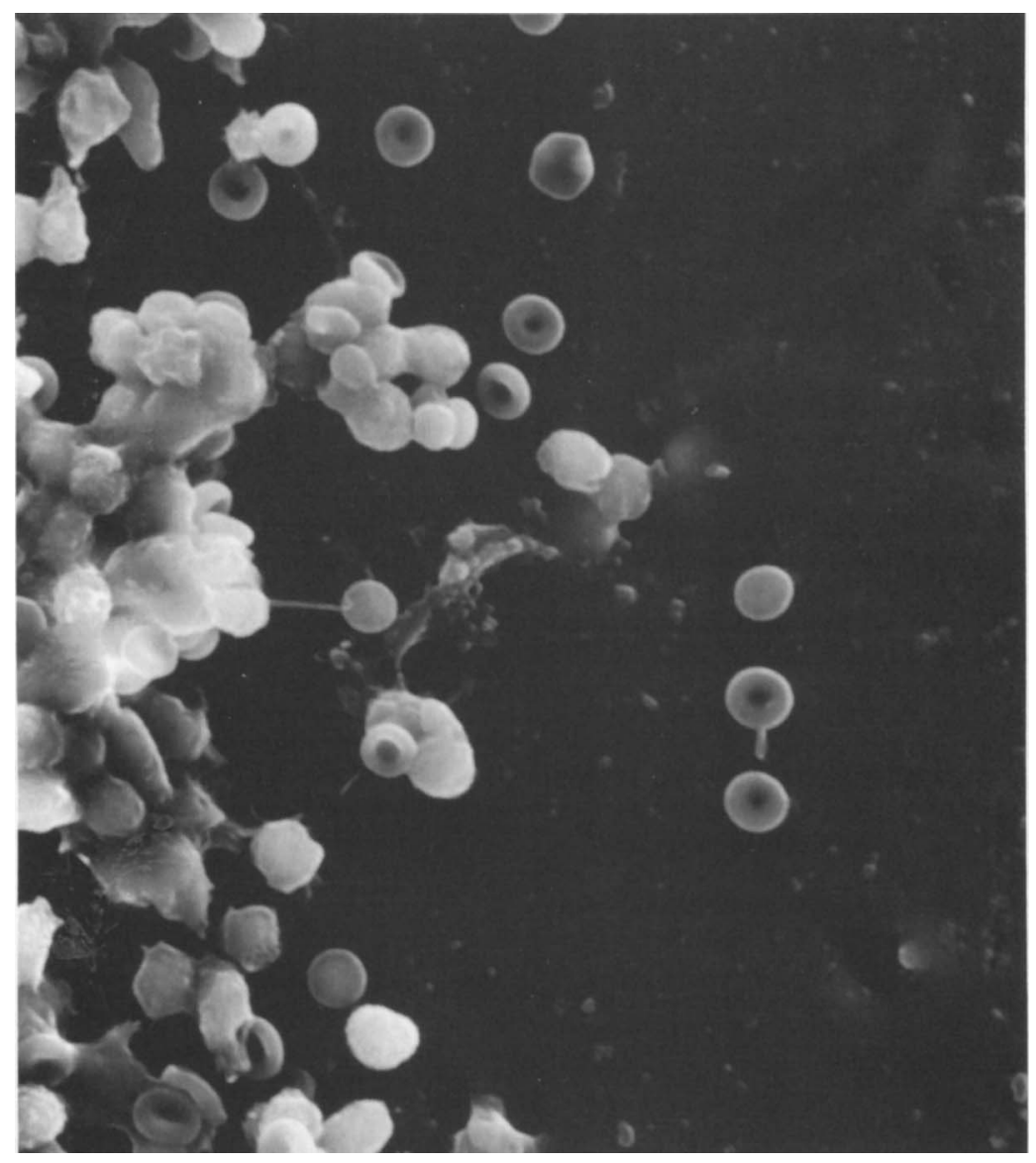

Fig. 6. Scanning electronmicrograph of a disk of the lifesaver device recovered from a group 2 rabbit after treatment with CIP microspheres. Note the absence of a biofilm.

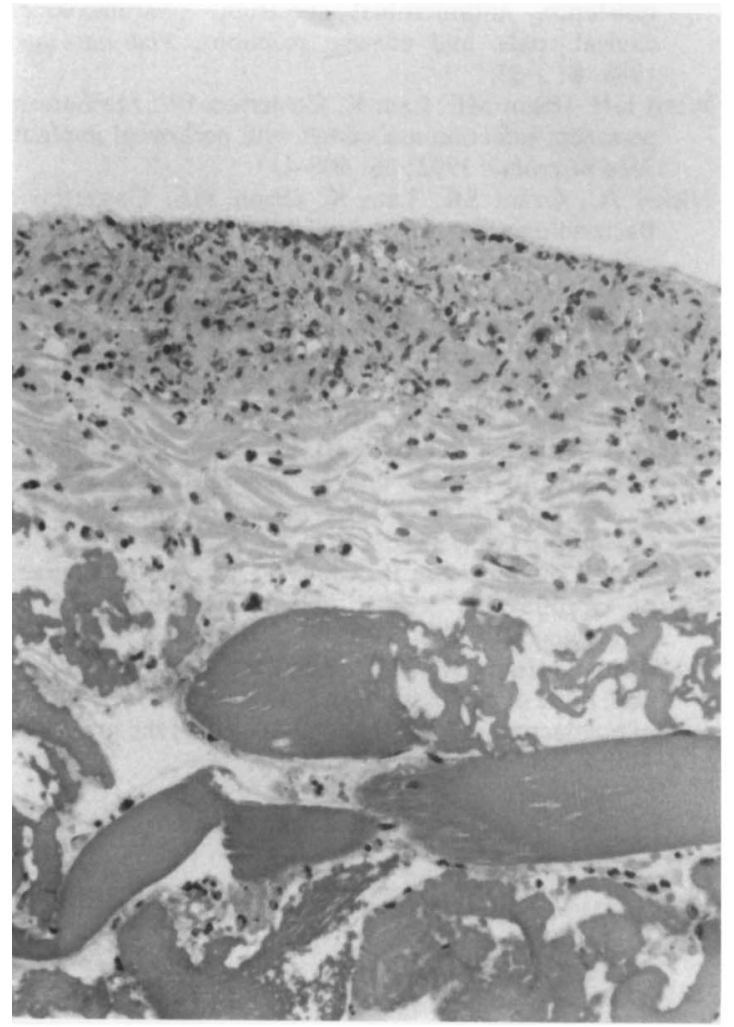

Fig. 7. Histology of peritoneal wall tissue from a group 1 rabbit. Note the thicker fibrous connective tissue (upper layer) and severely inflamed muscle (lower layer) ( $\times 14.5$ magnification).

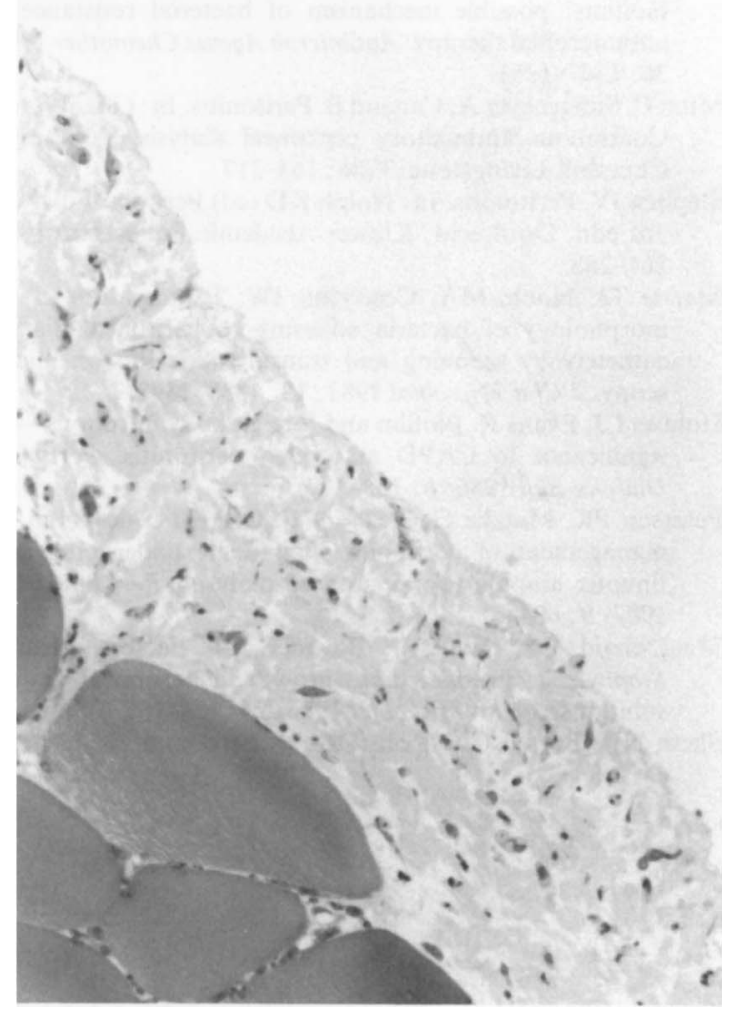

Fig. 8. Histology of peritoneal wall tissue from a group 2 rabbit. The fibrous connective tissue (upper layer) and muscle (lower layer) are normal ( $\times 14.5$ magnification). 
that treatment can be successful at lower serum concentrations of CIP if higher, effective peritoneal concentrations are maintained for $24-48 \mathrm{~h}$ by dosing every $12 \mathrm{~h}$. This approach may be applicable to other antibiotics that previously have been shown to be ineffective in vivo against biofilm-related infections;

\section{References}

1. Costerton JW. Cheng K-J, Geesey GG et al. Bacterial biofilms in nature and disease. Annu Rev Microbiol 1987; 41: 435-464

2. Gristina AG. Biomaterial-centred infection: microbial adhesion versus tissue integration. Science 1987 ; 237: 1588-1595.

3. Dougherty SH. Pathology of infection in prosthetic devices. Rev Infect Dis 1988; 10: 1102-1117.

4. Sells CJ, Shurtleff DB, Loeser JD. Gram-negative cerebrospinal fluid shunt-associated infections. Pediatrics 1977; 59: 614-618

5. Costerton JW. Lam J, Lam K, Chan R. The role of the microcolony mode of growth in the pathogenesis of Pseudomonas aeruginosa infections. Rev Infect Dis 1983; 5 Suppl 5: S867-S873.

6. Kunin CM. Steele C. Culture of the surfaces of urinary catheters to sample urethral flora and study the effect of antimicrobial therapy. J Clin Microbiol 1985; 21 : 902-908.

7. Hanker JS, Giammara BL. Biomaterials and biomedical devices. Science 1988; 242: 885-892.

8. Anwar H, Strap JL, Costerton JW. Susceptibility of biofilm cells of Pseudomonas aeruginosa to bactericidal actions of whole blood and serum. FEMS Microbiol Lett 1992; 92 $235-242$.

9. Anwar H, Costerton JW. Enhanced activity of combination of tobramycin and piperacillin for eradication of sessile biofilm cells of $P$ seudomonas aeruginosa. Antimicrob Agents Chemother 1990: 34: 1666-1671.

10. Anwar H. Dasgupta MK. Costerton JW. Testing the susceptibility of bacteria in biofilms to antibacterial agents. Antimicrob Agents Chemother 1990; 34: 2043-2046.

11. Anwar H. Strap JL. Costerton JW. Establishment of aging biofilms: possible mechanism of bacterial resistance to antimicrobial therapy. Antimicrob Agents Chemother 1992 ; 36: $1347-1351$.

12. Mion C, Slingeneyer A, Canaud B. Peritonitis. In: Gokal R (ed) Continuous ambulatory peritoneal dialysis. Edinburgh. Churchill Livingstone. 1986: 163-217.

13. Stephen IV. Peritonitis. In: Nolph KD (ed) Peritoneal dialysis, 3rd edn. Dordrecht, Kluwer Academic Publishers. 1989: $261-288$.

14. Marrie TJ. Noble MA, Costerton JW. Examination of the morphology of bacteria adhering to peritoneal dialysis catheters by scanning and transmission electron microscopy, J Clin Microbiol 1983; 18: 1388-1398

15. Holmes CJ, Evans R. Biofilm and foreign body infections-the significance to CAPD associated peritonitis. Peritoneal Dialysis Bull 1986; 6: 168-177.

16. Peterson PK, Matzke G, Keane WF. Current concepts in the management of peritonitis in patients undergoing continuous ambulatory peritoneal dialysis. Rev Infect Dis 1987; 9: 604 612.

17. MacDonald WA. Watts J, Bowmer MI. Factors affecting Staphylococcus epidermidis growth in peritoneal dialysis solutions. J Clin Microbiol 1986; 24: 104-107.

18. Sheth NK. Bartell CA, Roth DA. In vitro study of bacterial they could also become effective if BECs are maintained for a long enough period of time. Furthermore, sustained delivery of antibiotic necessary to eradicate the bacteria could reduce the incidence of the development of resistant strains, which is becoming a serious problem.

growth in continuous ambulatory peritoneal dialysis fluids. $J$ Clin Microbiol 1986; 23: 1096-1098.

19. Verbrugh HA, Keane WF, Conroy WE, Peterson PK. Bacterial growth and killing in chronic ambulatory peritoneal dialysis fluids. J Clin Microbiol 1984; 20: 199-203.

20. de Paepe $M$, Lameire N, Belpaire F, Bogaert M. Peritoneal pharmacokinetics of gentamicin in man. Clin Nephrol 1983; 19: 107-109.

21. Friedland JS, Iveson TJ, Fraise AP, Winearts CG, Selkon JB, Oliver DO. A comparison between intraperitoneal ciprofloxacin and intraperitoneal vancomycin and gentamycin in the treatment of peritonitis associated with continuous ambulatory peritoneal dialysis (CAPD). $J$ Antimicrob Chemother 1990; 26 Suppl. F: 77-81.

22. Ludlam HA, Barton I, White L, McMullin C, King A, Phillips I. Intraperitoneal ciprofloxacin for the treatment of peritonitis in patients receiving continuous ambulatory peritoneal dialysis (CAPD). $J$ Antimicrob Chemother $1990 ; 25$ : 843-851.

23. Dryden MS, Wing AJ, Phillips I. Low dose intraperitoneal ciprofloxacin for the treatment of peritonitis in patients receiving continuous ambulatory peritoneal dialysis (CAPD). J Antimicrob Chemother 1991; 28 : 131-139.

24. Kampf D, Borner K, Hain H, Conrad W. Multiple-dosekinetics of ofloxacin after intraperitoneal application in CAPD patients. Perit Dial Int 1991; 11: 317-321.

25. Rogers JA, Owusu-Ababio G. Formulation of antibiotics in polymeric microcapsules. II. Ciprofloxacin. Proc Int Symp Control Rel Bioact Mater 1993; 20: 354-355.

26. Owusu-Ababio, G. Sustained release antibiotic microspheres for eradication of bacterial biofilm. PhD Thesis, University of Alberta, Edmonton, Alberta, Canada, 1994.

27. Marc L. Ciprofloxacin: chemistry, mechanism of action, resistance, antimicrobial spectrum, pharmacokinetics, clinical trials, and adverse reactions. Pharmacotherapy $1988 ; 8: 3-33$.

28. Ward KH, Olson ME, Lam K, Costerton JW. Mechanism of persistent infection associated with peritoneal implants. $J$ Med Microbiol 1992; 36: 406-413.

29. Nickel JC, Grant SK, Lam K, Olson ME, Costerton JW Bacteriologically stressed animal model of a new closed catheter drainage system with microbicidal outlet tube. Urology 1991; 38 : 280-289.

30. Bassey CM, Baltch AL, Smith RP. Comparative antimicrobial activity of enoxacin, ciprofloxacin, amifloxacin, nonfloxacin and ofloxacin against 177 bacterial isolates. $J$ Antimicrob Chemother 1986; 17: 623-628.

31. Nickel JC, Ruseska I, Wright JB, Costerton JW. Tobramycin resistance of Pseudomonas aeruginosa cells growing as a biofilm on urinary catheter material. Antimicrob Agents Chemother 1985; 27: 619-624.

32. Nicholov R, Khoury AE, Bruce AW, DiCosmo D. Interaction of ciprofloxacin loaded liposomes with Pseudomonas aeruginosa cells. Cells Materials 1993; 3: 321-326.

33. Brady JM, Cutright DE, Miller RA, Battistone GC. Resorption rate, route of elimination, and ultrastructure of implant site of polylactic acid in the abdominal wall of the rat. $J$ Biomed Mater Res 1973; 7: 155-166. 